\title{
Analysis on the Possibility of Investment in the Mexican Emerging Market
}

\author{
Shizheng Wei \\ School of Management and Economics, Beijing Institute of Technology Beijing, 102100, China
}

\begin{abstract}
Emerging markets with high uncertainty and turbulent environments are always hard to predict. Unlike advanced markets that are not easy to be influenced by the external environment, emerging markets are still immature and likely to be easily affected. The Mexican peso crisis in 1994 is an example that inappropriate monetary policy was taken when the entire financial system was weak in Mexico at that time. In the global emerging market, Mexican peso plays a significant role in maintaining the stability of the foreign exchange market. This paper aims to analyze the current situation of Mexican domestic emerging markets from its economy, the monetary policy of the central bank of Mexico, and foreign exchange aspects. The analysis can provide information for potential investors to make a decision before they decide to invest in the Mexican emerging markets.
\end{abstract}

\section{INTRODUCTION}

With the frequently global trades between different countries, more and more developing countries are having a booming economy. Compared with those developed countries, emerging markets have more unexplored and potential opportunities. Therefore, a great deal of foreign investors is willing to put their money in the emerging market. However, emerging markets are more unpredictable because of its internal and external environments. As a result, risks are inevitable to the potential investors. When an investor makes a decision whether to invest in the Mexico emerging market, he needs to have a clear understanding towards the ongoing trend of the market, potential risks and profitability. This paper aims to give some analysis to the current Mexico domestic emerging markets based on historical statistic, and to find out if the current Mexican domestic market has a booming future in a short-term, if the central bank of Mexico has the adequate foreign exchange reserve to resist huge capital outflow, if the monetary policy is suitable and up-to-date, and if the volatility of exchange rate is stable or has mildly fluctuations.

\section{THE GLOBAL DOWNWARD TREND IN THE ECONOMY}

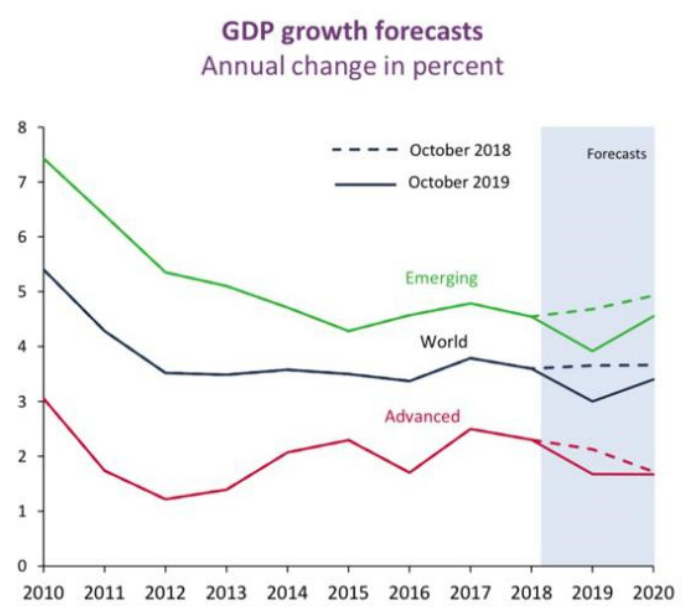

Figure 1. GDP growth in the past decade 


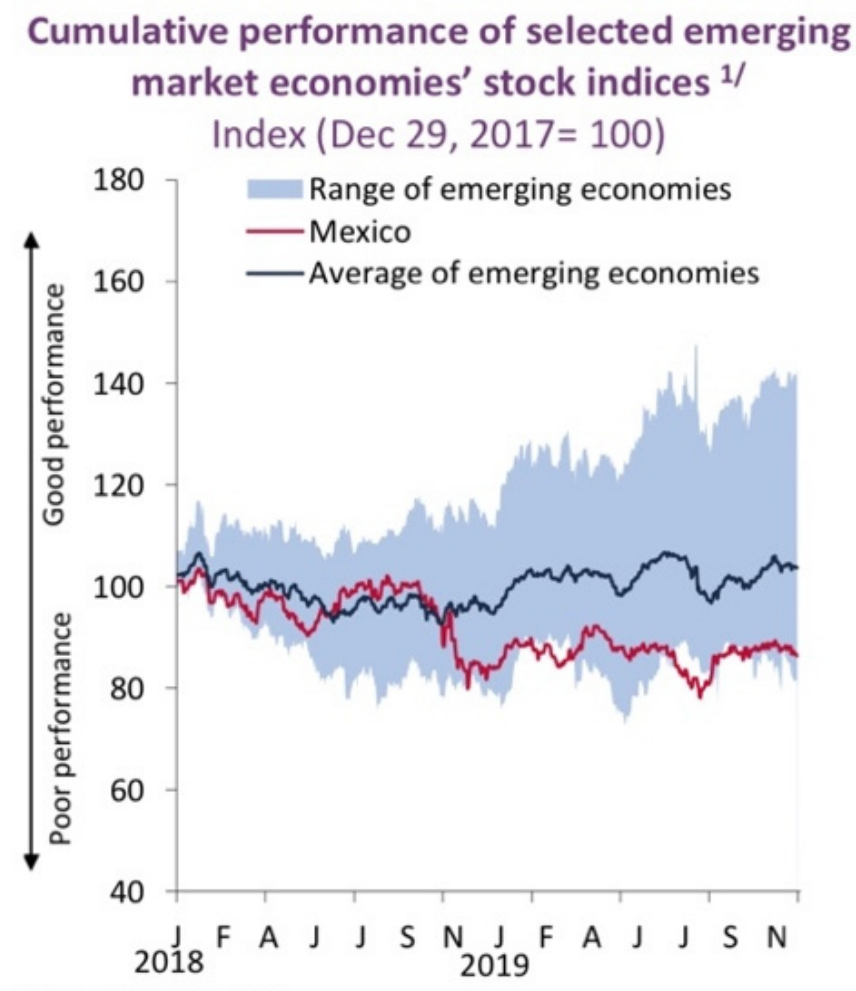

Data as of December 2019.

Source: Banco de México with Bloomberg data.

1/ Average for the following emerging economies: Argentina, Peru, Turkey, Philippines, Poland, Hungary, Indonesia, Russia, Colombia, Chile, Malaysia, India, Brazil and South Africa.

Figure 2. Cumulative performance of selected emerging market economics' stock indices

According to the Mexican central bank annual financial report in 2019, global economic growth in the past ten years is trending down. Moreover, Mexico's performance is lower than the average of the emerging market, nearly at the bottom of the range [4].

As Chiquiar pointed out that Mexico's low competitiveness reflects that the current institutional framework, market structures is rigid, which is unhelpful to the productive activities, investments and development of superior technologies [6]. The downward trend in the Mexican domestic economy will decrease Mexican peso's attractiveness compared to other exchange markets. As a result, the Mexican domestic markets may not be a suitable market for short-term investors.

\section{MEXICAN PESO TURNOVER}

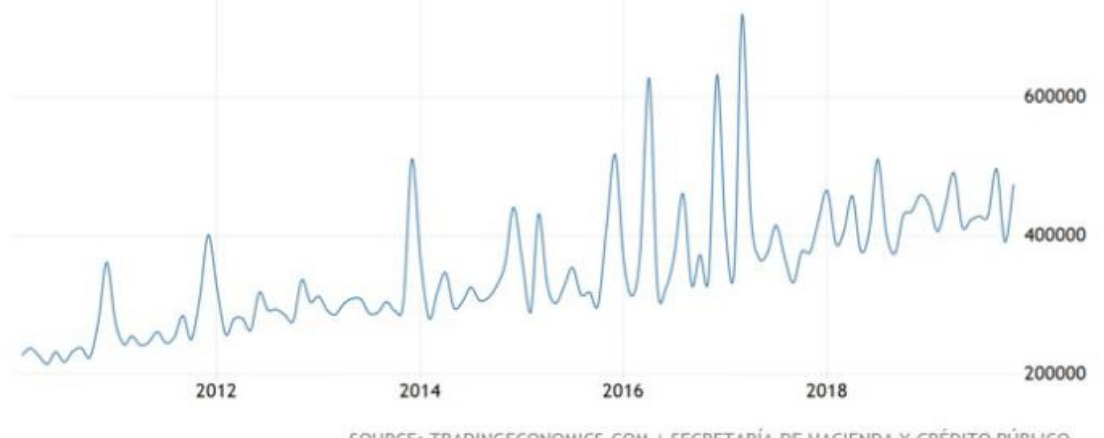

SOURCE: TRADINGECONOMICS.COM I SECRETARIA DE HACIENDA Y CRÉDITO PÚBLICO

\begin{tabular}{|lllllll|}
\hline Actual & Previous & Highest & Lowest & Dates & Unit & Frequency \\
\hline 473438.10 & 391173.50 & 719218.90 & 12748.50 & $1990-2019$ & MXN Million & Monthly \\
\hline
\end{tabular}

Figure 3. Turnover in Mexican peso during the past ten years 
During the past decade, the turnover of the Mexican peso has a mild upward trend, accompanied by periodic fluctuations. In 2009, the turnover was slightly over 200 billion pesos, and this figure turned out to be approximate 500 billion pesos ten years later. During the decade, the turnover reached an all-time high of MXN 719 billion in March of 2017. Based on this general information, the prediction was made that the turnover of MXN will decrease to 410 billion MXN in the first half of the year of 2020 and finally remain at approximately MXN 450 billion [4]. Generally, the Mexican peso turnover still had an upward trend in the past decade, which means the attractiveness of Mexican peso is

strengthening. However, the fluctuation during the decade was significant with a sharp increase and a decrease in one or two years. This situation is not a mature behavior in the economy because the Mexican peso is likely to be influenced by external factors. Thus, it will provide uncertainty in both of its domestic emerging market and foreign exchange market. Investors need to consider their ability to accept in high-level fluctuation before investing in the markets. Nevertheless, from a long term perspective, the Mexican domestic market does have potential opportunities.

\section{MEXICAN GDP AND INFLATION}

\section{Gross Domestic Product}

Quarterly \% change, s. a.

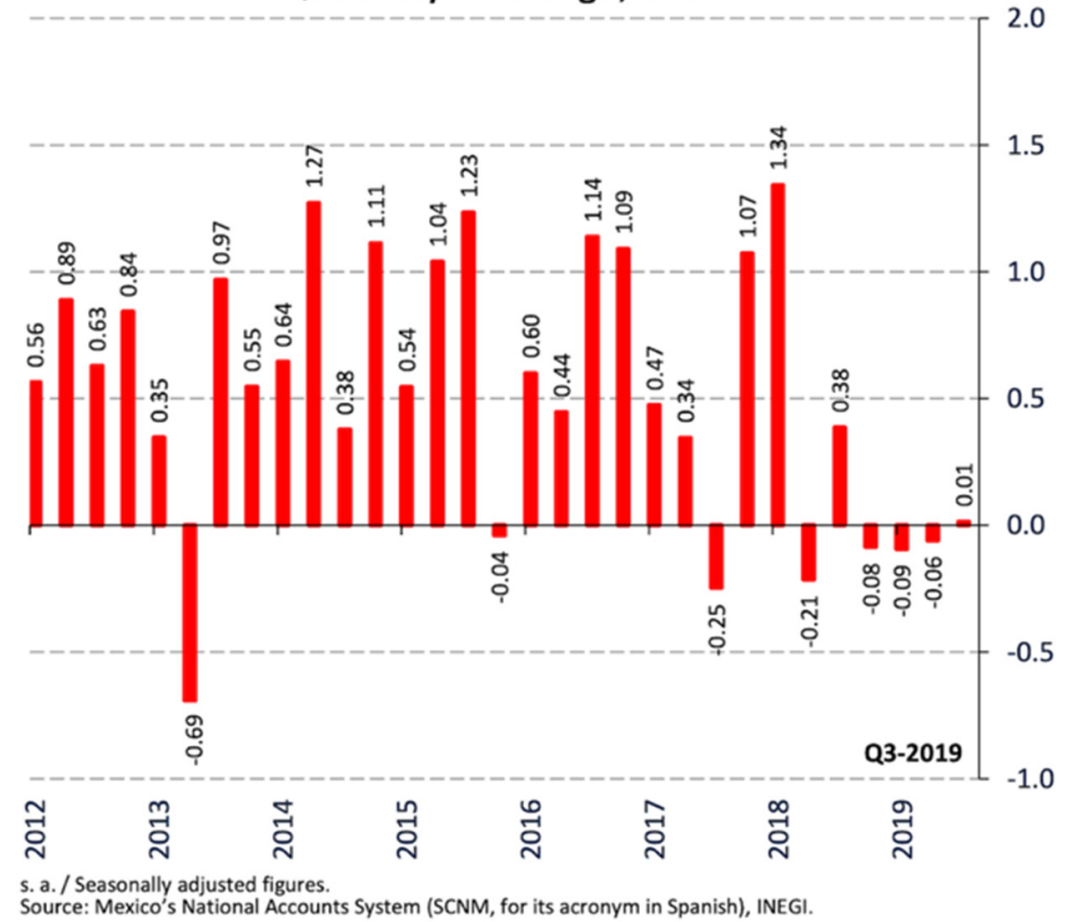

Figure 4. Quarterly changes in gross domestic product

According to the latest revision of Mexican GDP data, it is apparent to see Mexico's economic activity declined during the past year and currently stagnates. This stagnation is accordant with the global downward trend output. The predicted ending of the situation will not be earlier than in the year 2021. Consequently, new activities of investments should be carefully considered in a short period. 


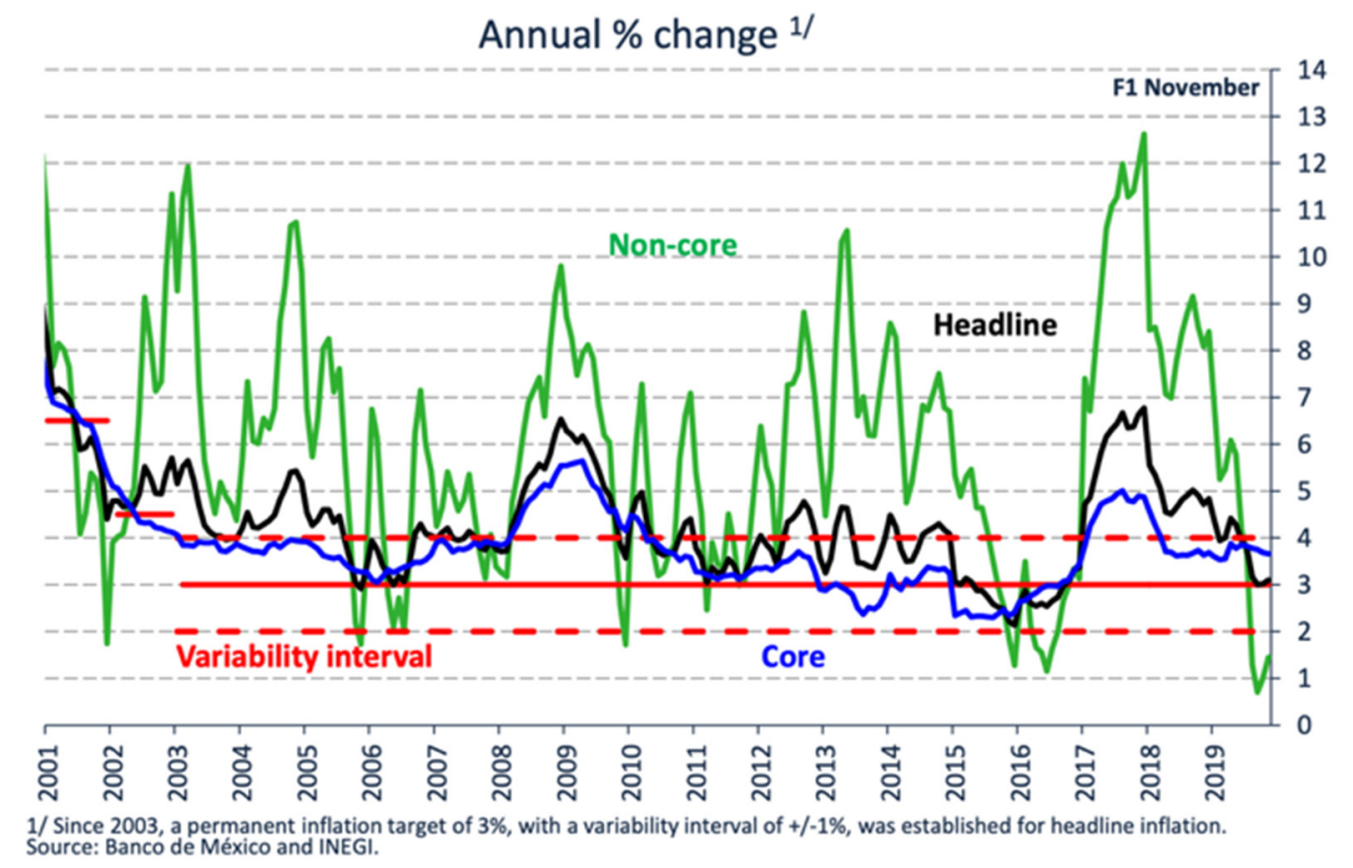

Figure 5. Annual percentage change in inflation from 2001 to 2020

This line graph shows the inflation change during the past decades (using consumer price index). In the second quarter of 2019 , the average annual headline inflation reached $4.21 \%$, and when it came to the third quarter, it stood out at $3.31 \%$. Apparently, the decline was because of the significant decline in non-core annual inflation. Simultaneously, annual core inflation fluctuated at a reasonable interval. Expectations for headline inflation for the end of 2019 could be below the forecasts of the Quarterly Report July-September 2019. For 2020, core and headline inflation will reflect both the greater amount of slack in the economy and the cost-related pressures resulting from the recent minimum wage revisions, which could locate them moderately above the levels anticipated in the last quarterly report. Relatively, the stable inflation rate in Mexico ensures the routine maintenance of the markets, which is kind to investments.

\section{MEXICAN FOREIGN EXCHANGE RESERVE}

Adequate foreign exchange reserves are essential to the stability of a market, especially when a considerable amount of capital is outflowing. In 1994, the Mexican government announced its decision to devalue the peso against the dollar by 14 percent, which led to a stampede to sell pesos as well as Mexican stocks and bonds. By early January 1995, the peso fell against the US dollar by as much as 40 percent. As a result, International investors reduced their holdings of emerging markets, which turned it into a global crisis [7]. During the decades, researches have been looking for the reasons behind the crisis, and weak banking system, overvalued exchange rate, and low foreign currency reserve were three common features found from those countries that suffered severe attack [11].

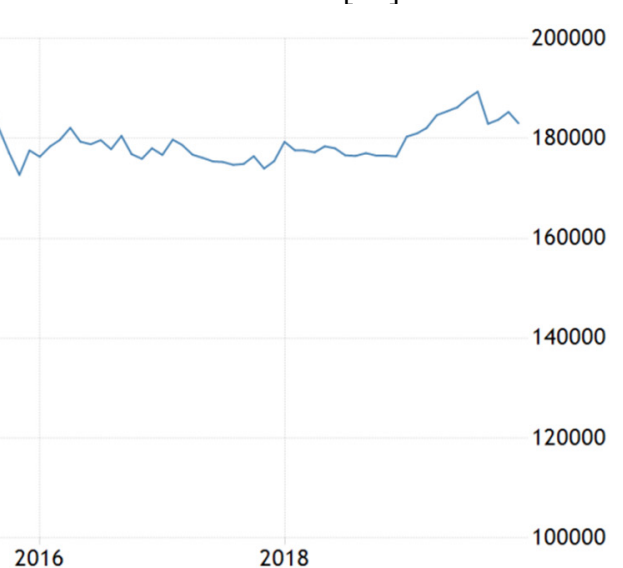

Figure 6. Mexican Foreign exchange reserve from 2010 to 2020, units: USD Million 
During the first half of the past ten years, the Mexican central bank increased its foreign exchange reserve, and then maintained it at approximately 180 billion USD. The highest point was 199 billion USD in 2015, and the reserve declined to 183 billion USD in December 2019. Generally speaking, the Mexican central bank has a certain ability to resist the potential outflow of capital and quickly adjust the domestic capital market. The possibility of a significant and uncontrollable depreciation in Mexican peso is kept at a low level.

\section{Monetary policy of the Mexican central bank}

During the past year, the Mexican central bank was consistently reducing its overnight interbank interest rate by 25 basis points per time to $7.25 \%$ on December 19 , 2019. According to the quarterly report July- September 2019 of the Mexican central bank, it announced that the central bank had conducted the monetary policy in a high uncertainty environment during the past year. The volatility was attributed to both of the internal and external factors like trade agreement assigned between the US and China, election results in Britain, and a consistent downward trend in the global economy. The press release also highlighted the difference between advanced financial markets and emerging markets. The former adjusted slightly while the latter, especially Latin America, faced different types of risks, volatility because of idiosyncratic factors [4].

According to what Allen has pointed out, a traditional focus on intermediation theory, such as transaction costs and asymmetric information, is less relevant in explaining the development of the banks as intermediaries [2]. Risk trading, risk management, and participation costs should be taken into account when considering the transformations [3].

The interest rate was $8.50 \%$ on February 07, 2019. Furthermore, during the whole year, the interest rate of Mexico declined four times and reached $7.25 \%$ on
December 19, 2019. The Mexican central bank announced that this is reasonable and within expectation. On the other hand, from national leader Donald Trump to Turkey's Recep Tayyip Erdogan, have been explicit in demanding lower borrowing costs to boost their economies as a global slowdown loom. However, unlike the US, the current environment of Mexico continues to pose risks that could affect the country's macroeconomic conditions, its ability to grow, and the economy's price formation process. In this regard, it is particularly important that, in addition to a prudent and firm monetary policy, measures to foster an environment of confidence and certainty for investment and higher productivity are adopted, and that public finances are consolidated in a sustainable way. From the monetary policy perspective, the Mexican central bank has consistently adjusted its policy to adapt to the change in markets, keeping the external risks in a lower rank. The central bank also compared its monetary policy with the US to emphasize stability. So, Investors have no need to worry about the possibility of the occurrence of an inappropriate monetary policy, like the announcement in 1994.

\section{CALCULATION OF VOLATILITY}

Rolling standard deviation is a widely used concept in economics for measuring the volatility of the exchange rate [10]. Also, some macroeconomics variables like GDP, interest rate, foreign reserves can affect volatility as well [8]. In addition to standard deviation, volatility has other variations, like using induced heavy moving averages [9], implied volatility, and using non-overlapping monthly volatility [12]. In this paper, the USD/MXN volatility in 2019 is calculated by using a standard formula of daily changes. This information may be useful to forecast volatility in 2020 and can be used to compare with weighted volatility, which uses different extensions of the ordered weighted average (OWA) operator [9].

Exchange rate (FIX)

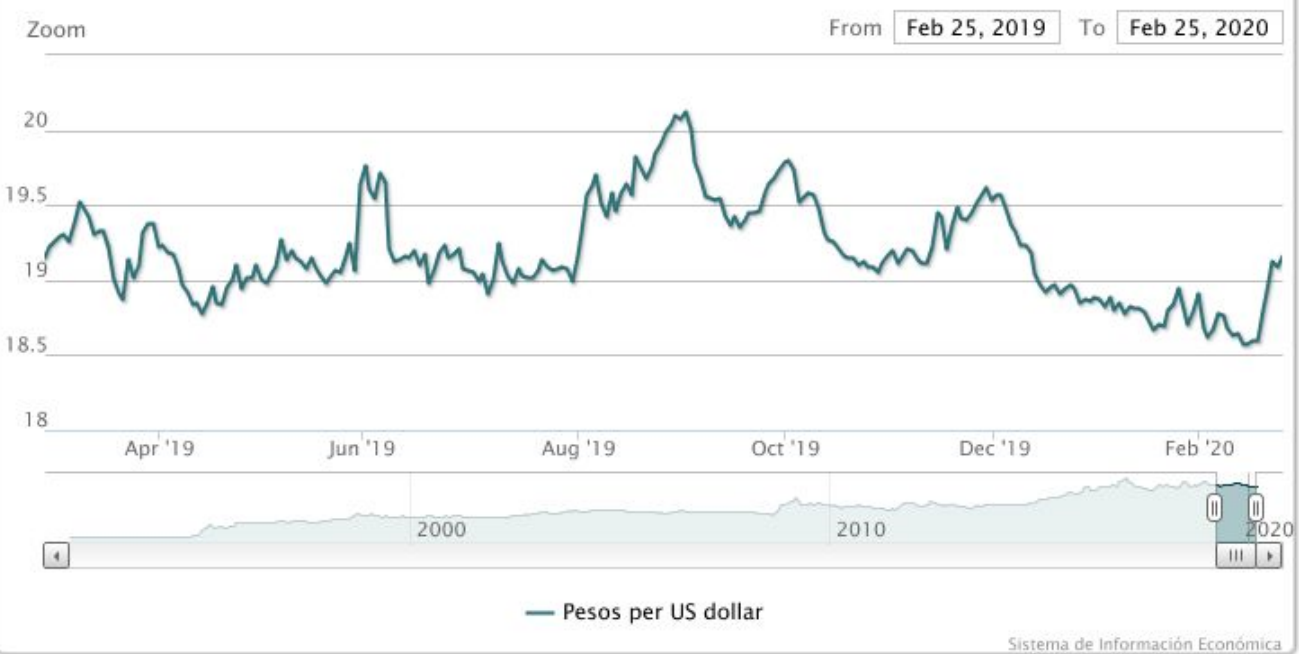

Figure 7. Exchange rate per US dollar from February 25th, 2019 to February 25th, 2020 
The exchange rate peso per US dollar has a slight fluctuation during the past year.
Table 1 lists the exchange rate, which was the 15th-day exchange rate each month, and volatility in each month is calculated using the standard formula.

Table 1. Exchange rate and monthly volatility

\begin{tabular}{|c|c|c|}
\hline \multirow{2}{*}{ Month } & USD/MXN & Monthly volatility \\
\hline February 25 & from February 25, 2019, to February 25, 2020 & 7.9 \\
\hline March 25 & 19.1630 & 8.8 \\
\hline April 25 & 19.0989 & 9.2 \\
\hline May 25 & 18.9414 & 7.8 \\
\hline June 25 & 19.0521 & 13.1 \\
\hline July 25 & 19.1442 & 7.5 \\
\hline August 25 & 19.0699 & 7.3 \\
\hline September 25 & 19.9086 & 5.9 \\
\hline October 25 & 19.6363 & 7.2 \\
\hline November 25 & 19.0820 & 4.8 \\
\hline December 25 & 19.5185 & 5.7 \\
\hline January 25, 2020 & 18.9445 & \\
\hline
\end{tabular}

Volatility

from February 25, 2019, to February 25, 2020

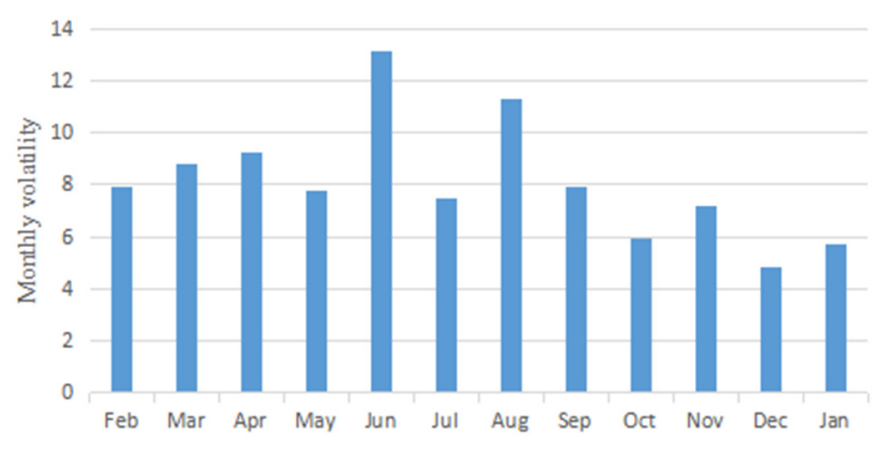

Figure 8. Volatility from February 2019 to January 2020

Volatility is an important factor when forecasting the future foreign exchange market. Risks bought by new strategies when exchange rates change can be predicted to some degree [9]. Forecast of volatility is important to market participants when they make decisions and many kinds of model use forecasts of volatility as a vital factor, like the option pricing model introduced by Black and Scholes [5]. As one of the main factors of the pricing of risky financial assets, the volatility of the exchange rate has been considered as a core direction of theoretical and empirical analysis. Various financial activities relied on the prediction or forecasts will be very useful to people who export products or potential investor in other countries. Like Sahoo has pointed out that, especially in emerging markets with high uncertainty and risks, the volatility of foreign exchange is vital for a potential investor to make decisions [12].

\section{CONCLUSION}

As an important part of the emerging market, the Mexican domestic markets do have potential opportunities for investments. And Mexico has many advantages for new investors like abundant foreign exchange reserves, consistent monetary policy, and mild fluctuation in core inflation. However, risks within its domestic markets are obvious for its downward trend in the economy, current stagnation, and its uncertainty in the foreign exchange market. Both of the global financial markets and the domestic markets are experiencing a downward period. Meanwhile, Mexico's economic activity stagnates in recent years, and it is easy to be influenced by the external environment. Furthermore, the 
entire structure of the market still needs time to reconsolidate and update in order to reduce the risks and uncertainty. All these factors indicate that investors should not expect high returns in a short period in the Mexican domestic emerging markets and should carefully consider the risks before investing.

\section{ACKNOWLEDGEMENT}

First and foremost, I would like to show my deepest gratitude to my teachers and professors, who have provided me with valuable guidance in every stage of the writing of this thesis. Further, I would like to thank all my friends and roommates for their encouragement and support. Without all their enlightening instruction and impressive kindness, I could not have completed my thesis.

\section{REFERENCES}

1. C. Alcaraz, S. Villalvazo. The effect of natural gas shortages on the Mexican economy. Energy Economics, 2017, vol. 66, pp. 147-153, viewed February 2020, $<$ http://search.ebscohost.com/login.aspx?direct=true $\& \mathrm{db}=$ buh $\& \mathrm{AN}=125021736 \&$ lang $=$ zh-cn\&site $=$ ehos t-live $>$.

2. F. Allen, A. M. Santomero. The theory of financial intermediation. Journal of Banking and Finance, 1997, vol. 21, no. 11-12, pp. 1461-1485.

3. N. A. M. Arif, et al. The Impact of Interest Rate Changes on the Islamic Foreign Exchange Forward in the Malaysian Derivative Market. Jurnal Pengurusan, 2019, vol. 56, pp. 1-15. Available at: http://search.ebscohost.com/login.aspx?direct=true\& $\mathrm{db}=$ buh\&AN=139367291\&lang=zh-cn\&site=ehost-1 ive (Accessed: February 12 2020).

4. Banco de México. Quarterly Report July September 2019. [online] Mexico: Banco de México, p.2. Available at: https://www.banxico.org.mx/publications-and-press/ quarterly-reports/\%7B634FD3B0-3AA2-56EC-5687 -350C6F371949\%7D.pdf [Accessed 26 Feb. 2020]

5. F. Black, M. Scholes. The Pricing of Options and Corporate Liabilities. Journal of Political Economy, 1973, vol. 81, no. 3, pp. 637-654.

6. D. Chiquiar, M. Ramos-Francia. Competitiveness and growth of the Mexican economy (No. 2009-11). Working Papers. 2009.

7. S. Cheol, B. G. Resnick. International Financial Management, Third Edition. New York: McGrawHill Companies, 2003, pp.47-48

8. A. Grossmann, I. Love, A. G. Orlov. The dynamics of exchange rate volatility: A panel VAR approach. Journal of International Financial Markets, Institutions and Money, 2014, vol. 33, pp. 1-27. https://doi.org/10.1016/j.intfin.2014.07.008

9. E. León-Castro, L. F. Espinoza-Audelo, E. Aviles-Ochoa., J. M. Merigó, J. A. Kacprzyk. New measure of volatility using induced heavy moving averages. Technological and Economic Development of Economy, 2019, vol. 25, no. 4, pp. 576-599. https://doi.org/10.3846/tede.2019.9374

10. A. G. Rabbani, J. E . Grable, W. Heo, L. Nobre, S. Kuzniak. Stock market volatility and changes in financial risk tolerance during the great recession. Journal of Financial Counseling and Planning, 2017, vol. 28, no. $1, \quad$ p. 140. https://doi.org/10.1891/1052-3073.28.1.140

11. Sachs et al. Financial crises in emerging markets: the lessons from 1995. Brookings Papers Econ. Act., 1996, no. 1, pp. 147-215

12. S. Sahoo, P. Trivedi. The Interrelationship Between Implied and Realized Exchange Rate Volatility in India. IUP Journal of Applied Economics, 2018, vol. 17, no. 4, pp. 7-26. Available at: http://search.ebscohost.com/login.aspx?direct=true\& $\mathrm{db}=$ buh\&AN=133637275\&lang=zh-cn\&site=ehost-1 ive (Accessed: February 28 2020). 